\title{
PENERAPAN MANAJEMEN STRATEGI DALAM DAKWAH NABI MUHAMMAD SAW
}

\author{
Walid Fajar Antariksa \\ e-mail: walidfjr@mpi.uin-malang.ac.id \\ FITK UIN Maulana Malik Ibrahim Malang
}

\begin{abstract}
Prophet Muhammad PBUH is a role model in every aspect of life. Many valuable lessons can be learned from his life. From the point of view of strategic management, every strategic decision that has been made by Prophet Muhammad PBUH in his dakwah in all kinds of diverse internal and external environment conditions is very much in line with modern strategy management science. This article tries to explain how strategic management applied by Prophet Muhammad PBUH especially in his da'wah so that now the Islamic religion spread all over the world.
\end{abstract}

Keywords: Prophet Muhammad, Strategic Management.

\section{Abstrak}

Nabi Muhammad saw merupakan contoh teladan dalam setiap aspek kehidupan. Banyak pelajaran yang berharga yang bisa diambil dari kehidupan beliau. Dari sudut pandang manajemen strategi, setiap keputusan strategis yang telah dilakukan oleh Nabi Muhammad saw dalam dakwahnya di segala macam kondisi lingkungan internal dan eksternal yang beragam adalah sangat sesuai dengan ilmu manajemen strategi yang modern. Artikel ini berusaha menguraikan bagaimana manajemen strategi yang diterapkan oleh Nabi Muhammad saw khususnya dalam dakwahnya sehingga kini agama Islam tersebar ke seluruh penjuru dunia.

Kata Kunci: Nabi Muhammad saw, Manajemen Strategi.

\section{Pendahuluan}

Manajemen strategi merupakan ilmu yang penting dimiliki oleh setiap pemimpin dan manajer yang sedang mengelola suatu organisasi untuk mencapi suatu tujuan. Manajemen strategi telah diterapkan sekian lama oleh para pemimpin dan ahli strategi selama ribuan tahun. Hingga kini ilmu tersebut terus berkembang dan terus digunakan dalam pengelolaan berbagai macam organisasi modern seperti pemerintah, perusahaan swasta hingga lembaga pendidikan. Beragam metode telah dikembangkan agar dapat menghasilkan strategi yang tepat demi tercapainya tujuan yang diharapkan dengan efektif dan efisien.

Dalam Islam, Nabi Muhammad Saw merupakan contoh teladan (uswatun khasanah) bagi setiap penganutnya. Hal ini dijelaskan di dalam Al-Quran, yaitu "Sesungguhnya telah ada pada (diri) Rasulullah itu uswatun hasanah (suri teladan yang baik) bagimu (yaitu) bagi orang yang mengharap (rahmat) Allah dan (kedatangan) hari kiamat dan dia banyak menyebut Allah." (QS. Al-Ahzaab: 21). Ketedananan yang diberikan oleh Nabi Muhammad saw memiliki makna yang sangat luas. Bukan hanya keteladanan dalam hal ibadah ritual keagamaan saja, melainkan keteladanan dalam seluruh sektor kehidupan., termasuk di dalamnya keteladanan dalam hal kepemimpinan dan manajemen.

Al Buthy (2008) menjelaskan bahwa kehidupan Rasulullah saw memberikan kepada kita contoh-contoh mulia, baik sebagai pemuda Islam yang lurus perilakunya dan terpercaya di antara kaum dan juga kerabatnya, ataupun sebagai da'i kepada Allah dengan hikmah dan nasehat yang baik, yang mengerahkan segala kemampuan utnuk menyampaikan risalahnya. Juga sebagai kepala negara yang mengatur segala urusan dengan 
cerdas dan bijaksana, sebagai suami teladan dan seorang ayah yang penuh kasih sayang, sebagai panglima perang ang mahir, sebagai negarawan ynag pandai dan jujur, dan sebagai Muslim secara keseluruhan (kaffah) yang dapat melakukan secara imbang antara kewajiban beribadah kepada Allah dan bergaul dengan keluarga dan sahabatnya dengan baik.

Menurut Choudhury dalam Ishak (2011), Nabi Muhammad saw bukan hanya seorang pemimpin spiritual yang sukses, tetapi juga merupakan pemimpin negara (stateman) dan administrator yang berjaya. Dalam konteks pembawa perubahan (reformer) Nabi Muhammad saw juga telah sukses menghasilkan revolusi yang signifikan dalam cara hidup dan pemikiran masyarakat Arab. Michael Hart (2016), seorang peneliti beragama Nasrani, dalam bukunya juga menempatkan Nabi Muhammad Saw sebagai tokoh paling berpengaruh nomor 1 sepanjang peradaban di dunia. Menurutnya nabi Muhammad berhasil meraih kesuksesankesuksesan yang luar biasa baik ditilik dari ukuran agama maupun ruang lingkup duniawi.

Nabi Muhammad saw dalam setiap aspek kehidupannya mengandung pelajaran yang sangat berharga. Artikel ini berusaha menguraikan bagaimana manajemen strategi yang diterapkan oleh Nabi Muhammad saw khususnya dalam dakwahnya sehingga kini agama Islam tersebar ke seluruh penjuru dunia.

\section{Konsep Manajemen Strategi}

\section{Pengertian Strategi}

Hunger dan Wheelen (2003) mendefinisikan strategi sebagai rumusan perencanaan komprehensif tentang bagaimana perusahaan akan mencapai misi dan tujuannya. Strategi akan memaksimalkan keunggulan kompetitif dan meminimalkan keterbatasan bersaing. Menurut Pearce dan Robinson (2008), strategi diartikan oleh para manajer sebagai rencana berskala besar dengan orientasi masa depan guna berinteraksi dengan kondisi persaingan untuk mencapai tujuan perusahaan.
Sedangkan menurut Stephanie K. Marrus seperti dikutip oleh Husein Umar (2008), strategi didefinisikan sebagai suatu proses penentuan rencana para pemimpin puncak yang berfokus pada tujuan jangka panjang organisasi disertai penyusunan suatu cara atau bagaimana agar tujuan tersebut dapat dicapai.

Dari beberapa pendapat di atas, maka dapat disimpulkan bahwa strategi adalah rencana yang komprehensif untuk mencapai tujuan utama organisasi atau perusahaan dengan memaksimalkan keunggulan dan meminimalkan keterbatasan.

\section{Pengertian Manajemen Strategi}

Pengertian Manajemen strategi menurut Pearce dan Robinson (2008) adalah satu set keputusan dan tindakan yang menghasilkan formulasi dan implementasi rencana yang dirancang untuk meraih tujuan suatu perusahaan.

Sedangkan Wheelen dan Hunger (2003) menjelaskan bahwa manajemen Strategi adalah serangkaian keputusan dan tindakan manajerial yang menentukan kinerja perusahaan dalam jangka panjang. Manajemen strategi meliputi pengamatan lingkungan, perumusan strategi (perencanaan strategis atau perencanaan jangka panjang), implementasi strategi dan evaluasi atau pengendalian.

Senada dengan pakar lainnya, Fred R. David (2006) mendefinisikan manajemen strategi sebagai suatu seni dan ilmu untuk memformulasikan, menerapkan, dan mengevaluasi keputusan-keputusan lintas fungsi, dengan itu maka organisasi bisa mencapai tujuan organisasi.

\section{Manfaat Manajemen Strategi}

Pearce dan Robinson (2008) menjelaskan bahwa penerapan manajemen strategi memiliki beberapa manfaat, yaitu:

1. Kegiatan perumusan (formulasi) strategi memperkuat kemampuan perusahaan mencegah masalah.

2. Keputusan strategi yang didasarkan pada kelompok mungkin sekali dihasilkan dari alternatif yang terbaik yang ada. 
3. Keterlibatan karyawan dalam perumusan strategi meningkatkan pemahaman mereka akan adanya hubungan produktivitas-imbalan di setiap rencana strategi dan, dengan demikian, mempertinggi motivasi mereka.

4. Senjang dan tumpang tindih kegiatan diantara individu dan kelompok berkurang karena partisipasi dalam perumusan strategi memperjelas adanya perbedaan peran masing-masing.

5. Penolakan terhadap perubahan berkurang.

\section{Proses manajemen Strategi}

Proses manajemen strategi menurut Pearce dan Robinson (2008) ada 3 tahap, yaitu:

1. Tahap perumusan atau formulasi strategi; Tahap ini termasuk mengembangkan visi serta misi, kemudian mengidentifikasi peluang dan ancaman eksternal perusahaan, menentukan kekuatan dan kelemahan internal, menetapkan tujuan jangka panjang, merumuskan alternatif strategi dan memilih strategi tertentu yang akan dilaksanakan.

2. Tahap implementasi strategi; Tahap ini mensyaratkan perusahaan untuk dapat menetapkan tujuan tahunan, membuat kebijakan, memotivasi karyawan, dan mengalokasikan sumber daya sehingga strategi yang telah dirumuskan dapat dilaksanakan. Tahap ini sering juga disebut tahap pelaksanaan dan sering juga disebut sebagai tahap yang paling rumit karena membutuhkan disiplin pribadi, komitmen dan pengorbanan.

3. Tahap evaluasi strategi; Tahap yang terakhir ini adalah tahapan dimana dapat diketahui apakah strategi yang telah ditetapkan berjalan sesuai dengan yang diharapkan. Evaluasi strategi adalah alat utama untuk mengetahui informasi tersebut.
Strategi dapat dimodifikasi karena faktor internal dan eksternal secara konstan berubah.

6. Penetapan Strategi dengan Analisis SWOT

Salah tahapan penting dalam manajemen strategi adalah tahap penetapan strategi. Salah satu metode yang sering digunakan dalam penetapan strategi adalah analisis SWOT. Menurut Erwin Suryatama (2014) analisa SWOT merupakan sebuah metode yang digunakan untuk mengevaluasi kekuatan, kelemahan, peluang dan ancaman dalam suatu proyek atau suatu spekulasi bisnis atau proyek yang mengindentifikasi faktor internal dan eksternal yang mendukung dan yang tidak dalam mencapai tujuan tersebut.

a. Kekuatan (Strengths) adalah situasi atau kondisi yang merupakan kekuatan dari organisasi atau program pada saat ini. Strength merupakan faktor internal yang mendukung perusahaan dalam mencapai tujuannya seperti sumber daya, keahlian atau kelebihan yang lain.

b. Kelemahan (Weakness) adalah kegiatan-kegiatan organisasi yang tidak berjalan dengan baik atau sumber daya yang dibutuhkan oleh organisasi tetapi tidak dimiliki oleh organisasi. Weakness merupakan faktor internal yang menghambat perusahaan dalam mencapai tujuannya. Faktor penghambat dapat berupa fasilitas yang tidak lengkap, kurang sumber daya keuangan, kemampuan mengelola keahlian pemasaran, dan citra perusahaan.

c. peluang (Opportunities) adalah faktor positif yang muncul dari lingkungan dan memberikan kesempatan bagi organisasi. Opportunity merupakanfaktor eksternal yang mendukung perusahaaan dalam mencapai tujuan. Faktor eksternal yang mendukung dalam pencapain tujuan dapat berupa peruabahan 
kebijakan,

linnsgkungan,

perubahan

supplier dan buyer.

d. Ancaman (Threats) adalah faktor negative dari lingkungan yang memberikan hambatan bagi berkembangnya atau berjalannya sebuah organisasi. Threat merupakan faktor eksternal ynag menghambat perusahaan dala mencapai tujuannya. Faktor eksternal yang menghambat perusahaan dapat berupa masuknya pesaing baru, pertumbuhan pasar yang lambat, maningkatnya bargaining power daripada supplier dan buyer utama, perubahan teknologi serta kebijakan baru.

David (2009) memberikan penjelasan bahwa matriks SWOT merupakan perangkat pencocokan yang penting untuk membantu manajer mengembangkan empat tipe strategi yaitu SO-WO-ST-WT.

a. Strategi SO atau strategi kekuatanpeluang menggunakan kekuatan internal perusahaan untuk memanfaatkan peluang eksternal.

b. Strategi WO atau strategi kelemahan-peluang bertujuan untuk memperbaiki kelemahan dengan memanfaatkan peluang eksternal.

c. Strategi ST atau strategi kekuatanancaman menggunakan kekuaran perusahaan untuk menghindari atau mengurangi dampak ancaman eksternal.

d. Strategi WT atau strategi kelemahan-ancaman merupakan taktik defensive yang diarahkan untuk mengurangi kelemahan internal dan menghindari ancaman eksternal.

Freddy Rangkuti (2009)

mengemukakan bahwa analisis SWOT adalah identifikasi berbagai faktor secara sistematis untuk merumuskan strategi perusahaan. Analisis ini didasarkan pada logika yang dapat memaksimalkan kekuatan (Strengths) dan peluang (Opportunities), namun secara bersamaan dapat meminimalkan kelemahan (Weaknesses) dan ancaman (Threats). Di bawah ini adalah model dari Matriks SWOT:

\section{Kekuatan}

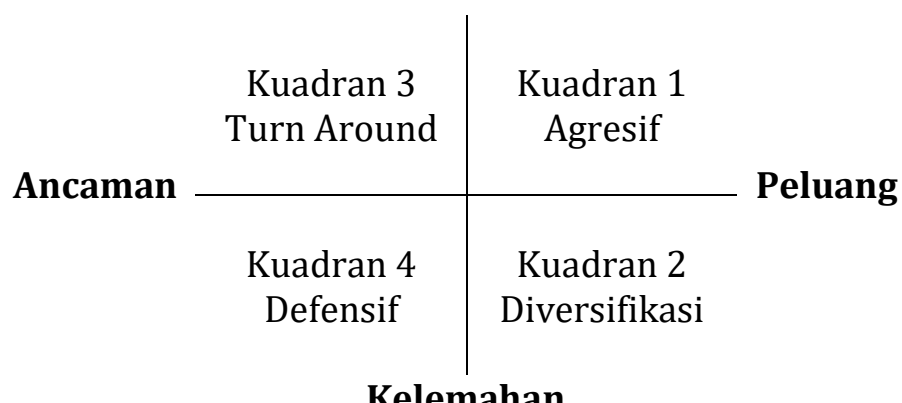

Kuadran 1: Ini merupakan situasi yang sangat menguntungkan. Perusahaan tersebut memiliki peluang dan kekuatan sehingga dapat memanfaatkan peluang yang ada. Strategi yang harus diterapkan dalam kondisi ini adalah mendukung kebijakan pertumbuhan yang agresif (Growth oriented strategy).

Kuadran 2: Meskipun menghadapi berbagai ancaman, perusahaan ini masih memiliki kekuatan dari segi internal. Strategi yang harus diterapkan adalah menggunakan kekuatan untuk memanfaatkan peluang jangka panjang dengan cara strategi diversifikasi (produk/pasar).

Kuadran 3: Perusahaan menghadapi peluang pasar yang sangat besar, tetapi dilain pihak ia menghadapai beberapa kendala/kelemahan internal. Fokus strategi pada kuadran ini adalah meminimalkan masalah-masalah internal perusahaan sehingga dapat merebut peluang pasar yang lebih baik.

Kuadran 4: Ini merupakan situasi yang sangat tidak menguntungkan, perusahaaan tersebut menghadapai berbagai ancaman dan kelemahan internal. 


\section{Praktek Manajemen Strategi Dakwah Nabi Muhammad Saw}

Nabi Muhammad merupakan Nabi terakhir yang diutus untuk menyempurnakan agama tauhid dengan diturunkannya Al Qur'an sebagai kitab suci untuk seluruh umat manusia. Sebelumnya Allah menurunkan kitab Zabur kepada Nabi Daud as, Taurat kepada Nabi Musa As, dan Injil kepada Nabi Musa As. Diiturunkannya Al Qur'an kepada nabi Muhammad saw adalah untuk menyempurnakan ajaran agama dan sebagai penutup para Nabi. Dengan ini Al Qur'an sebagai kitab penyempurna yang berarti tidak ada lagi Nabi setelah Nabi Muhammad dan tidak ada lagi kitab yang lebih sempurna dari Al Qur'an. Karena itulah Nabi Muhammad dengan berpedoman pada Al Qur'an sebagai firman Allah serta dengan petunjuk Allah, melakukan tugasnya sebagai Nabi dan Rosul mendakwahkan Islam sebagai agama terakhir dan agama yang paling sempurna.

Nabi Muhamad saw menerima wahyu untuk pertama kalinya di usia 40 tahun. Dan kemudian wahyu terus turun secara berangsur-angsur selama 22 tahun 2 bulan 22 hari. Selama itu pula Nabi Muhammad melakukan dakwah dalam beragam kondisi dan dengan beragam strategi. Menurut Al Buthy(2008), dakwah Islamiyah di masa hidup Nabi saw, sejak penerimaan wahyu pertama hingga wafat, menempuh empat tahapan :

1. Pertama, Dakwah secara rahasia, selama tiga tahun.

2. Kedua, Dakwah secara terangterangan dengan menggunakan lisan saja tanpa perang, berlangsung sampai hijrah.

3. Ketiga, Dakwah secara terangterangan dengan memerangi orangorang yang menyerang dan memulai peperangan atau kejahatan. Tahapan ini berlangsung sampai tahun perdamaian Hudaibiyah.

4. Tahapan keempat, Dakwah secara terang-terangan dengan memerangi setiap orang yang menghalangi jalannya dakwah atau menghalangi orang yang masuk Islam setelah masa dakwan yang pemberitahuan dari kaum musyrik, anti agama atau penyembah berhala. Pada tahapan inilah syariat Islam dan hukum jihad dalam Islam mencapai kemapanan.

Nabi Muhammad saw sesuai dengan sejarah hidupnya menghadapi berbagai macam situasi yang berbeda dalam dakwahnya. Dari sudut pandang manajemen strategi, khususnya dengan menggunakan analisis SWOT, maka pilihan ada 4 macam kondisi yang berbeda yang dihadapi oleh Nabi Muhammad saw. Dan 4 kondisi ini berbesuaian dengan pembagian tahapan dakwah Nabi Muhamad saw yang disampaikan oleh Al Buthi(2008). 4 macam kondisi yang bersesuaian dengan tahapan tersebut yaitu:

1. kondisi dimana lingkungan internal lebih besar kekuatan dibanding kelemahan, sedangkan di lingkungan eksternal lebih besar peluang dibanding ancaman. Ciri kondisi ini sesuai dengan fase Madinah akhir.

2. kondisi dimana lingkungan internal lebih besar kekuatan dibanding kelemahan, sedangkan di lingkungan eksternal lebih besar ancaman dibanding peluang. Ciri kondisi ini sesuai dengan fase Madinah awal.

3. kondisi dimana lingkungan internal lebih besar kelemahan dibanding kekuatan, sedangkan di lingkungan eksternal lebih besar peluang dibanding ancaman. Ciri kondisi ini sesuai dengan fase Makkah akhir.

4. kondisi dimana lingkungan internal lebih besar kelemahan dibanding kekuatan, sedangkan di lingkungan eksternal lebih besar ancaman dibanding peluang. Ciri kondisi ini sesuai dengan fase Makkah awal.

Untuk lebih memudahkan penjelasan dapat dilihat pada diagram berikut : 


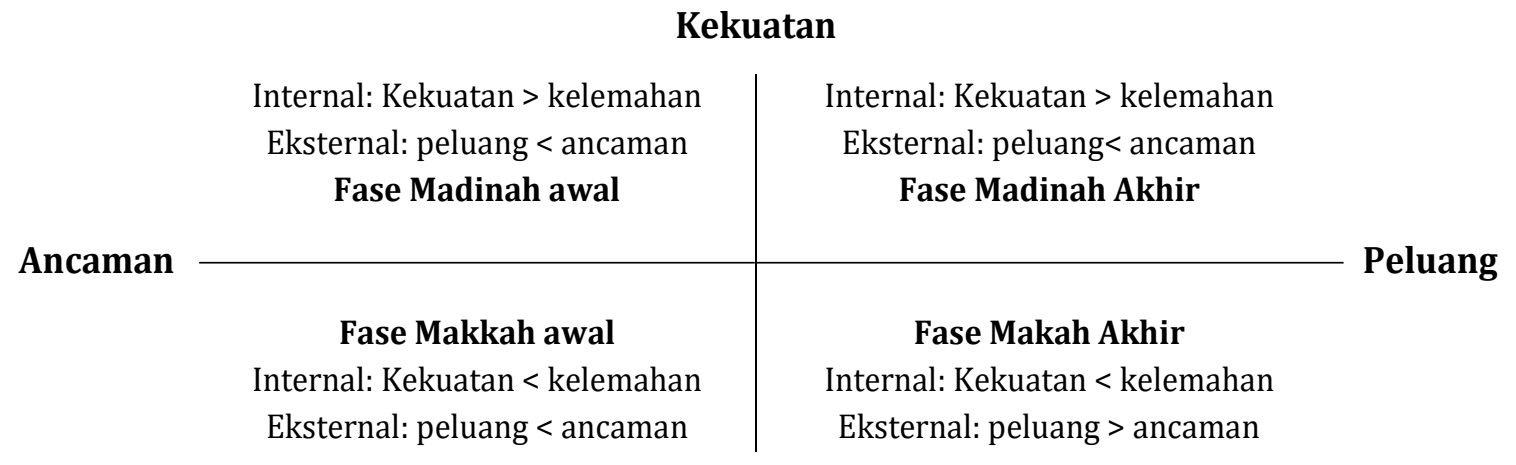

Kelemahan

\section{Fase Makkah awal}

Periode ini dimulai dari awal masa kenabian, yaitu ketika nabi Muhammad saw mendapatkan wahyu pertama di gua Hiro'. Pada fase ini kondisi Nabi Muhammad dan umat Islam masih lemah secara internal dan penuh ancaman secara eksternal. Berdasarakan teori manajemen strategi yang moderen, strategi yang tepat untuk digunakan dalam posisi ini adalah strategi bertahan(defensif), yaitu dengan mengurangi kelemahan dan menghindari ancaman dari luar. Dan sejarah mencatat bahwa strategi dakwah yang dilakukan Nabi Muhammad dan sahabat di fase ini diawali dengan dakwah secara rahasia. Nabi Muhammad mengawali dakwahnya kepada orang terdekatnya yaitu keluarga, saudara dan sahabat dekatnya.

Al Buthy(2008) memberikan penjelasan bahwa orang-orang yang pertama kali masuk Islam ialah Khadijah binti Khuwailid r.a., Ali bin Abi Thalib, Zaib bin Haritza mantan budak Rasulullah saw, dan anak angkatnya, Abu Bakar bin Abi Qufahah, Ustman bin Affan, Zubair bin Awwam, Abdurrahman bin Auf, Sa'ad bin Abi Waqqash dan lainnya. Mereka ini bertemu dengan Nabi secara rahasia. Apabila salah seorang di antara mereka ingin melaksanakan salah satu ibadah, ia pergi ke lorong-lorong Mekkah seraya bersembunyi dari pandangan orang-orang Quraisy. Ketika orang-orang yang menganut Islam lebih dari tiga puluh lelaki dan wanita, Rasulullah saw. memilih rumah salah seorang dari mereka, yaitu rumah al-Arqam bin Abi al-Arqam, sebagai tempat pertemuan untuk mengadakan pembinaan dan pengajaran. Dakwah pada tahapan ini menghasilkan sekitar empat puluh lelaki dan wanita telah menganut Islam. Kebanyakan mereka adalah orangorang fakir, kaum budak dan orang-orang Quraisy yang tidak memiliki kedudukan.

Dari sudut pandang manajemen strategi, keputusan berdakwah secara rahasia yang dipilih oleh Nabi Muhammad sudah sangat tepat. Walaupun dari aspek spiritual Nabi Muhammad saw sebagai utusan Allah tentunya bisa saja melakukan dakwah secara terang-terangan di awal dengan penjagaan dari Allah swt, namun beliau memilih menyampaikan dakwahnya secara rahasia dan tersembunyi. Pada fase Makkah awal, kondisi kaum muslimin dari sisi internal jumlah masih sedikit dan secara sebagian besar di antara mereka adalah orang miskin dan budak yang tidak memiliki kekuatan. Dan dari sisi eksternal risiko penolakan dan ancaman yang mungkin timbul bisa jadi sangat besar. Sehingga ketika memilih untuk dakwah secara terang-terangan di fase ini kemungkinan besar menjadi kurang efektif dan efisien. Sedangkan jika Nabi Muhammad saw memilih untuk hanya berIslam sendiri tanpa melakukan dakwah, maka tujuan penyebaran risalah Islam tentunya menjadi sulit dicapai oleh beliau. Maka dari itu keputusan strategis untuk berdakwah secara diam-diam adalah keputusan yang memang tepat.

\section{Fase Makkah Akhir}

Pada fase ini kondisi yang dihadapi oleh Nabi Muhammad saw kalau dilihat dari Dzohir (luar) adalah dari sisi internal masih banyak kelemahan dibandingkan 
dengan kekuatannya. Hal ini terlihat dari masih sedikitnya jumlah orang yang sudah memeluk Islam secara kuantitas dan ditambah lagi bahwa mereka sebagian besar berasal dari kalangan yang lemah. Akan tetapi dari sisi eksternal Nabi Muhammad saw sebagai seorang pemimpin yang visioner dapat melihat banyaknya peluang dibanding ancaman yang ada, mengingat tujuan dakwahnya adalah untuk seluruh umat manusia bukan hanya untuk orang Arab di kota Makkah.

Salah satu keputusan strategis yang diambil oleh Nabi Muhammad saw adalah dakwah secara terang-terangan yang dimulai dengan beliau saw mengumpulkan keluarga besarnya dan menyampaikan dakwahnya kepada seluruh yang hadir secara langsung. Setiap keputusan yang diambil dan dijalankan pasti akan mempunyai dampak, baik dampak positif maupun dampak negatif. Dalam teori investasi dikenal istilah high risk high return yang maksudnya dalam pengambilan keputusan semakin tinggi hasil yang ingin dicapai maka akan menghasilkan risiko yang tinggi pula. Tindakan Nabi Muhammad saw melakukan dakwah secara terang-terangan pun memiliki risiko yaitu rasulullah dan pengikutnya akhirnya ditolak dan dimusuhi oleh sebagian besar kaum kafir Quraisy. Di sisi lain keputusan strategis ini memberikan dampak positif, yaitu tersebarnya berita dengan masif bahwa Muhammad saw merupakan utusan Allah yang membawa agama Islam sebagai agama penyempurna. Dan berita ini pun menyebar sampai ke luar kota Makkah dan membuat orang-orang yang mendapatkan berita ini menjadi tertarik untuk mengetahui tentang Islam dan kemudian masuk Islam.

Keputusan strategis Nabi Muhammad saw yang lain di fase ini adalah dengan memerintahkan sebagian kaum muslimin untuk melakukan hijrah ke negri Habasyah. Keputusan ini tentunya sangat tepat mengingat lingkungan eksternal di kota makkah masih sangat tidak aman dan penuh ancaman. Pemilihan Habasyah sebagai tempat tujuan hijrah pun merupakan bentuk pemilihan strategi yang sangat akurat. Nabi Muhammad saw sendiri yang memilih Habasyah sebagai tempat tujuan hijrah dengan pertimbangan informasi bahwa di Habasyah ada seorang Raja yang adil yang akan memberikan perlindungan. Dari sini kita bisa mengambil pelajaran bahwa informasi merupakan sumber daya yang penting dalam perumusan strategi. Dan ini membuktikan bahwa Nabi Muhammad saw sebagai pemimpin menerapkan prinsip strategi yang tepat, yaitu memanfaatkan peluang untuk menutupi kelemahan.

$$
\text { Keputusan strategis Nabi }
$$

Muhammad yang berikutnya adalah melakukan hijrah ke Thaif. Peristiwa ini dilakukan setelah meninggalnya paman sekaligus pelindung Nabi Muhammad saw di kota Makkah. Dari sisi manajemen strategi, hijrah ke kota lain, dalam istilah manajemen bisa disamakan dengan mencari terget yang baru, sebenarnya merupakan keputusan yang tepat mengingat dakwah nabi di kota Makkah sulit berkembang dan penuh ancaman. Meskipun demikian, strategi yang tepat tidak selalu membuahkan hasil yang memuaskan. Di kota Thaif dakwah Nabi Muhammad saw ditolak dan bahkan diusir dan dilempari batu hingga terluka. Pelajaran yang bisa diambil secara manajemen strategi disini adalah bahwa kita harus terus melakukan upaya yang baru(diversifikasi) untuk mencapai tujuan, apalagi jika berdiam pada pilihan strategi yang lama tidak membuahkan hasil yang signifikan atau bahkan mengalami penurunan.

Keputusan strategis yang lain adalah dengan berdakwah kepada para kabilah yang datang dari luar kota Makkah pada musim haji. Ibnu Sa'd di dalam Thabaqat-nya, sebagaimana dikutib oleh Al-Buthy(2008), berkata, "Pada setiap musim haji Rasulullah saw mendatangi dan mengikuti orang-orang sedang menunaikan haji sampai ke rumah-rumah mereka dan di pasar-pasar 'Ukazh, Majinnah dan Dzi'l-Majaz. Beliau mengajak mereka agar bersedia membelanya sehingga ia dapat menyampaikan risalah 
Allah, dengan imbalan surga bagi mereka. Tetapi Rasulullah saw tidak mendapat seorangpun yang membelanya."

Keputusan tersebut merupakan strategi yang sangat tepat mengingat pada musim haji banyak kabilah dari luar kota Makkah datang untuk beribadah di Makkah. Secara prinsip ekonomi keputusan ini sangat efisien karena Nabi Muhammad tidak perlu menghabiskan waktu dan tenaga untuk mendatangi mereka masing-masing di wilayahnya yang jauh dan berbeda-beda. Meskipun demikian hasil baik yang diharapkan baru terealisasi pada tahun ke-11 dari kenabian yaitu ketika kabilah dari Madinah bersedia menerima dakwah Nabi Muhammad saw dan memeluk Islam. Kemudian pada tahun haji berikutnya kabilah dari Madinah yang menerima dakwah dan memeluk Islam semakin banyak dan bahkan mereka bersedia menjadi pelindungnya. Hal ini kita kenal dengan peristiwa baiat Aqobah. Dan baiat Aqbah ini menjadi awalan yang tepat untuk keputusan strategis Nabi Muhamad saw yang berikutnya yakni hijrah ke Madinah.

\section{Fase Madinah Awal}

Pada fase ini Nabi Muhammad saw menghadapi situasi dimana kondisi internal umat Islam di Madinah sudah semakin kuat, akan tetapi kondisi eksternalnya masih lemah dengan besarnya ancaman yang datang dari kaum kafir Quraisy di Makkah. Strategi yang dilakukan oleh Nabi Muhammad saw pada fase ini adalah strategi Turn around yaitu memperkuat kondisi internal umat Islam dan meminimalkan ancaman yang ada. Beberapa keputusan strategis yang dibuat antara lain: membangun masjid, mempersaudarakan kaum muhajirin dan kaum anshor, hingga melakukan perjanjian dengan kaum non muslim yaitu dengan piagam Madinah.

Ketika Rasulullah di Madinah, beliau meletakkan asas-asas masyarakat Islam yang kemudian hal ini mampu melahirkan sebuah peradaban baru di dunia dan bagi dunia Islam khususnya. Asas asas tersebut antara lain al-Ikha (persaudaraan), al-Musawah (persamaan),
al-Tasamuh(toleransi), al-Ta 'awun (tolong menolong) dan al-'Adalah (keadilan) (Khaldun, 2014).

Di Madinah, proses persaudaraan (muakhah) yang dilakukan atas dasar keimanan antara muhajirin dan anshor telah membentuk suatu heterogenitas baru masyarakat Madinah yang juga dihuni oleh kaum Yahudi. Reformasi sosial politik Nabi ditandai dengan terbitnya Piagam Madinah yang meletakkan dasar-dasar hubungan sosial politik semua warga Madinah(Haris, 2006).

Perjanjian piagam madinah merupakan keputusan strategis besar yang dilakukan Nabi Muhammad saw pada fase Madinah awal. Salah satu maksud dari isi piagam madinah adalah bahwa kaum muslimin, baik dari kelompok Muhajirin (orang yang berhijrah dari Makkah) dan Anshor (orang yang menolong dari Madinah) serta kaum non muslim di Madinah saling bekerja sama dan saling menjaga dari ancaman musuh.

Pada fase ini, kebijakan Nabi Muhammad saw yang telah ditetapkan di awal diuji dengan peristiwa-peristiwa kritis, seperti: Perang Badar, pengusiran Bani Qoinuqa' dari Madinah, Perang Uhud, Perang Khandaq hingga perang Bani Quraidhah. Beberapa perang yang terjadi di fase ini merupakan perang dalam rangka membela diri. Ini membuktikan bahwa di lingkungan eksternal, ancaman yang ada masih sangat besar. Ancaman tersebut terutama berasal dari kaum kafir Quraisy di Makkah dan kaum Yahudi di Madinah dan sekitarnya.

$$
\text { Fase ini diakhiri dengan }
$$

terlaksananya perjanjian Hudaibiyah, yakni perjanjian damai yang salah satu isinya adalah adanya gencatan senjata antara kaum Muslimin dan kaum kafir Quraisy. Fatimah (2009) menjelaskan terdapat hikmah dari Perjanjian Hudaibiyah diantaranya adalah berkembangnya syiar Islam, kehidupan masyarakat menjadi lebih aman dan damai, membuka jalan kepada pembebasan kota Makkah dari musyrikin Quraisy, dan orang Islam dapat membuat perhubungan dengan kabilah Arab yang lain. Dengan 
adanya perjanjian Hudaibiyah, maka secara umum dari sisi eksternal ancaman utama yang ada, yaitu serangan dari kaum kafir Quarisy, menjadi tidak signifikan.

\section{Fase Madinah Akhir}

Fase Madinah akhir ini dimulai dari perjanjian Hudibiyah. Pada fase ini kondisi umat Islam secara internal sudah sangat kuat, sedangkan secara eksternal peluang yang ada lebih besar dibandingkan dengan ancaman. Sehingga strategi yang diterapkan oleh Nabi Muhammad saw adalah strategi agresif. Keputusan strategis yang dilakukan oleh Nabi Muhammad pada fase ini adalah: perang khaibar, pengiriman utusan ke negri yang lain, Perang Mu'tah, Fathu Makkah, Perang Hunain dan perang tabuk.

Pengiriman surat dakwah ke negrinegri di luar Arab merupakan salah satu keputusan strategis Nabi Muhammad saw dalam mengoptimalkan peluang setelah adanya perjanjian damai. Pengiriman surat dakwah itu antara lain ditujukan ke Raja Najasyi di Habasyah, Raja al-Maquqis di Mesir, Raja Heracius di Romawi, Raja Kisra di Persia dan Penguasa Romawi di Bashra. Ada yang menerima Dakwah Nabi Muhammad saw secara langsung, ada yang tegas menolak dan ada pula yang mengambang (tidak menerima dan juga tidak menolak secara langsung).

Pada fase ini sejarah mencatat terjadinya beberapa peperangan yang dilakukan oleh kaum muslimin yang sifatnya tidak sekedar mempertahankan diri akan tetapi menyerang. Namun hal ini bukan berarti Nabi Muhammad saw memaksa orang lain untuk masuk ke dalam agama Islam dengan kekerasan. Hal ini sesuai dengan ayat di dalam Al-Quran yang menjadi pedoman umat Islam, yaitu "Tidak ada paksaan dalam memeluk agama. Sungguh telah jelas antara kebenaran dan kesesatan"(QS. Al Baqarah: 256).

Nabi Muhammad saw melakukan perang karena adanya suatu sebab peristiwa yang mendahului dan memicu. Perang Mu'tah misalnya. Perang ini penyebabnya adalah karena utusan Nabi Muhammad saw ke Raja Romawi dibunuh oleh pihak Romawi. Atas sebab itulah kemudian Nabi Muhammad saw mengirimkan pasukan kaum muslimin untuk menyerang Romawi di wilayah Mu'tah. Nabi Muhammad saw melakukan juga penyerangan pada peristiwa perang Khaibar. Musthafa As-Siba'i(2009) menjelaskan bahwa pemicu terjadinya perang khaibar adalah karena kaum Yahudi di Khaibar melakukan makar, provokasi dan konspirasi untuk menjatuhkan Nabi Muhammad saw dan kaum Muslimin. Sehingga perang Khaibar dilakukan untuk menyingkirkan ancaman dari kaum Yahudi yang seringkali mengganggu instabilitas kaum Muslimin di Madinah, bukan dalam rangka melakukan pemaksaan agama.

Keputusan strategis yang paling memberikan dampak secara signifikan pada fase ini adalah pembebasan kota Makkah atau sering disebut peristiwa Fathu Makkah. Nabi Muhammad saw berangkat dengan membawa pasukan yang besar untuk menyerang kaum kafir Quraisy di Kota Makah. Pemicunya adalah sekutu dari pihak kaum kafir Quraisy Makkah melanggar perjanjian Hudaibiyah dengan menyerang kelompok yang berpihak pada kaum Muslimin. Dan pelanggaran perjanjian tersebut segera ditindaklanjuti oleh Nabi Muhamad saw dengan memberangkatkan 10.000 pasukan dimana beliau turut serta memimpin pasukan tersebut. Pada peristiwa ini kaum muslimin mendapatkan kemenangan yang nyata, yaitu dengan terbebasnya kota Makkah dari penguasaan kaum kafir Quraisy.

Jika dulu pada fase Makkah awal ketika kaum muslimin dihina dan disiksa bahkan sampai ada yang terbunuh, nabi Muhammad saw tidak langsung menyerang maka di fase Madinah Akhir keputusan strategis yang dipilih cukup berbeda. Nabi Muhamad saw akan segera melakukan perlawanan ketika ada kedzaliman atau pelanggaran perjanjian. Keputusan Nabi Muhamad saw yanng berbeda ini, jika dilihat dari sudat pandang ilmu manajemen strategi, menunjukkan bahwa beliau penuh perhitungan yaitu dengan memperhitungkan faktor kekuatan 
dan kelemahan di lingkungan internal kaum muslimin serta melihat besarnya peluang dan ancaman di luar. Ketika kondisinya berbeda, maka keputusan strategis yang diambil pun tidaklah sama.

\section{Kesimpulan}

Nabi Muhammad saw merupakan contoh teladan dalam setiap aspek kehidupan. Banyak pelajaran yang berharga yang bisa diambil dari kehidupan beliau. Dari sudut pandang manajemen strategi, setiap keputusan strategis yang telah dilakukan oleh Nabi Muhammad saw dalam dakwahnya di segala macam kondisi lingkungan internal dan eksternal yang beragam adalah sangat sesuai dengan ilmu manajemen strategi yang moderen. Walaupun apabila dipandang dari sudut pandang spiritualitas Nabi Muhammad saw yang merupakan utusan Allah swt pasti yakin bahwa akan dijaga oleh Allah, namun beliau tetap melakukan dakwahnya dengan strategi yang matang. Dari sini kita bisa mengambil pelajaran bahwa untuk pengelolaan dakwah atau kegiatan positif lainnya kita perlu menggunakan manajemen strategi yang tepat yaitu dengan melakukan analisis lingkungan dalam hal kekuatan, kelemahan, peluangan maupun ancaman sehingga kemudian bisa menggunakan strategi yang tepat untuk mencapai tujuan.

\section{Daftar Pustaka}

Al-Qur'an al-Karim dan Terjemahannya

Al-Buthy, Muhammad Said Ramadhan. 2008. Sirah Nabawiyah: Analisis ilmiah manhajiah Sejarah pergerekan Islam di Masa Rasululloh Saw. (terjemahan Aunur Rafiq Shaleh). Jakarta: Robbani Press.

David, Fred R. 2006. Manajemen Strategi. Jakarta: Salemba Empat

Fatimah, Siti. 2009. Dakwah Struktural: Studi Kasus Perjanjian Hudaibiyah. Jurnal Dakwah, Vol. X No. 1, JanuariJuni 2009. UIN Sunan Kalijaga.

Haris, Ahmad. 2006. Nabi Muhammad dan Reformasi Masyarakat Arab. Kontekstualita 21 (2). http://e- journal.iainjambi.ac.id/index.php/ko ntekstualita/article/view/110.

Hart, Michael H. 2006. 100 Tokoh paling berpengaruh di dunia, edisi revisi. Jakarta: Noura Book

Ishak, Suraiya. 2011. Kepemimpinan Etika Berlandas Sirah Nabi Muhammad Saw. Jurnal Hadhari 3 (2) tahun 2011. Universiti Kebangsaan Malaysia.

Khaldun, Rendra. 2014. Muhammad Sebagai Nabi dan Negarawan. KOMUNITAS 6 (1): 41-58.

Pearce, John. A. dan Robinson, Richard B. Jr. 2008. Manajemen Strategik: Formulasi, Implementasi dan Pengendalian. (Terjemahan Ir. Agus Maulana). Jakarta: Salemba Empat.

Rangkuti, Freddy. 2004. Analisis SWOT Teknik Membedah Kasus Bisnis. Jakarta: PT. Gramedia Pustaka Utama

Suraiya Ishak. 2011. Model Kepemimpinan Etika Berlandas Sirah Nabi Muhammad SAW. Jurnal Hadhari 3 (2): 23-44.

Suryatama, Erwin. 2008. Lebih Memahami Anlisis SWOT dalam Bisnis. Jakarta: Kata Pena

Wheelen, Thomas L. \& J.D. Hunger. 2003. Manajemen Strategis. (Terjemahan Julianto Agung). Yogyakarta: Andi.

Umar, Husein. 2008. Strategic Management in Action. Jakarta: PT Gramedia Pustaka Utama 